\title{
Permanent Peace Amid The Warlike World
}

\author{
Tigran Babasyan
}

Honorary Doctor of the International Academy of Sciences on Nature and Society

doi: 10.19044/esj.2017.v13n13p114 URL:http://dx.doi.org/10.19044/esj.2017.v13n13p114

\begin{abstract}
Until now the dichotomy of war and peace has tracked two paths: one in tune with the Roman maxim «In peace prepare for war» and the other begotten by the ongoing apocalyptic craze for the end of the world and could be tentatively worded like this: "Wage wars to get peace." Meanwhile there is a flexible and fairly feasible construct to operate in order to reach the balance in war- and -peace things. It is the cause-and- effect relation where war always stands for the effect that, weirdly enough, stems from peace. Does it mean that the real cause of war is engendered in peace? It usually is that way if the peace is established on a loose soil: but when built on the solid ground it devours all those who are in the way of peace. We mean the river of eternal life flowing between the two dichotomic banks: "I will send peace flowing over her (Jerusalem) like a river, and the wealth of nations like a stream in flood.” (Isaiah 66:12) (The New English Bible,1970). How to reach the banks of this river of disambiguation will be the thrust of our deliberations below.
\end{abstract}

Keywords: Religion, political science, ethics, nation state, stray culture

“There is no peace for the wicked, says the Lord” (Isaiah 57:21).

\section{Methodology}

The methodology of this article rests on my concept of a "religiopolitical module”. It is a novelty in the social sciences and is predicated on the symbiosis of the secular and the ecclesiastical approaches to the entire gamut of multidisciplinary issues relating to society as the breeding ground of the fundamental notions of "peace' and "war ". "Peace" is the emanation of the divine justice in the life of civil society. In terms of peace- securing the nation state, as perceived and construed in the Christian breath (Romans :13, in particular), is a causa sine qua non. "War" is a condition where a state, even though officially declared "national", fails to ensure the necessary prerequisites for the rule of peace, i.e. divine justice. Basically, any war is 
the spillover of the aggregate of unsolved socio-economic and administrative issues into the external medium; a war is due to the ideological inconsistency inside a "failed state" (in reality governed by the insiders of pagan clans in the Western administrations), and in this regard any war is begotten and waged internally first and later, on maturation, either is launched into outer political space ( Babasyan:, 2015, pp.55-60) or transamutes into the ideological upheaval generally known as revolution (Seagle., 1946, p.23).

The significance of the religious component of my concept is substantiated by a simple truth that religion has been the oldest source of knowledge (science), administrative and financial patterns behind different social formations (politics) and, consequently, is present in the life of the modern global commonwealth as well (Sabine, 1958). Hence the confluence of secular and religious doctrines on statehood I call ideology (my study focuses on the potentialities of enhancing the rapport between the Western political tradition and the the Christian doctrine it is ideologically, though covertly,basing upon). I have prioritized and highlighted the significance of the Christian doctrine in order to harmonize the exisitng political reality swayed by the Western polities and the Bible as the source of recurrent political patterns towards ensuring lasting peace. For the purposes of this particular article I have been rigorous on quite worthwhile ideas of prominent researchers from different fields (Keynes ; Spencer H, 1960; Ehrlich Eugen,1936; Max Weber, 1919; Max Weber, 1921; P. Vicente and D. Kaufmann, 2006; De Soto Hernando, 2000, and others). A comprehensive analysis of their seminal concepts is delivered in my article "Secular Economy as viewed from Christian Perspective” (Babasyan, 2015). The thrust of my study, however, is to motivate a possibly prescriptive solution to the hands-on issues by rendering them less descriptive as it is the case with the above scholars representing, to a varying degree, the mainstream science.

The proposed symbiosis (religion and politics) largely draws upon the elaboration of the modalities towards convergence of the secular and sacerdotal doctrines on building a reliable model of a statehood that would enable a sustainable peace. In this regard I accentuate the importance of a "nation state" as the driving force behind the global peacemaking. The origin of the "nation state" I attribute to the definition of the "nation”provided in the Bible: (1 Peter 2: 9-10). It is hugely importgant to identify the potential adversary to the peaceful processes: Stray Cultures one more novelty I have introduced into the scientific circulation. These ethno-religious agglomerations stand for hardcore separatism and religious extremism. The application of the term "Stray Cultures" in the sociopolitical research significantly facilitates the identification, analysis, prognostication, prevention or neutralization of these cultures which are 
pronounced exponents of Neopaganism fermenting all global conflicts (their behavioral pattern is described in my "Covert Actuality: Stray Cultures Launch World War III", 2015). This study has captured a typical trend of a steady and targeted numerical growth of the pagan quota of the population of the nation/Christian state towards the seizure of the power leverages therein. This enables the pagan constituency to make the Western Constitutions work for their interests, i.e. depletion of the unity and peace of the general Christian citizenry and in this way - demolition of the state system strenuously and devotedly built by the Christian governments of the West. Under these conditions a "peace" established by the West proves to work in favor of the neopaganism/stray cultures which by mobilizing their efforts ( also internationally) try to ruin the nation state from within (instance the ongoing developments throughout Western democracies) (Saunders, 2012, 786-810,). The aim of these subversive actions is one: remove the existing bulwark of peace and to build a bridgehead for their military expansion. Obviously, wars are the modus vivendi inherent in stray cultures /neopaganism.

Based on the reasons stated in the foregoing, one can rightfully state that the modern political system of the West is a prolonged reverberation of the pagan tradition in the Christian reality (limited possibilities of the legal positivism, overly flexible religious toleration, and thinning national immunity) and therefore needs to be revamped. This condition necessitates a closer and purposeful cooperation between the ecclesiastical and the secular powers of the West towards the neutralization of the potential enemy (in particular, by introducing respective precepts of the Christian doctrine as amendments in the legislations and Constitutions at large).

Finally, the implementation of the above measures will secure the viability of the concept expounded by Brzezinski and Huntington: only the political systems with pronounced adherence to the democratic principles of Western political culture (in religious terms implying the precepts of monotheism of Christianity undergirding the secular system) can be the guarantors of international peace, since they manage to uphold peace nationally as well as internationally. This is the only modality of securing permanent peace amid the warlike world.

\section{Introduction}

As if in tune with the scintillating recent predictions of the pontiffs of political science - the likes of Brzezinski and Huntington, in particular, - the global slot-machine is ejecting customary apocalyptic evils in form of soft toys designed for the vast masses of peccable global community to cushion the painful experiences from occasional bruises dealt on each other while continuing to play tough games. As the political science is reaching the 
vanishing point of political reason which largely connotes also the end of the bifurcated statehood, the concomitant crescendo of the global cacophony is becoming ever more challenging. Henceforth there is no room left for meandering reasons of the importance of the state as the only bulwark of organized society. "Short of a deliberate or unintentional American abdication, the only real alternative to American global leadership in the foreseeable future is international anarchy. In that respect, it is correct to assert that America has become, as President Clinton put it, the world's 'indispensable nation'.” (Brzezinski, 1997, p.195). That's at least how the state as the historical phenomenon is unanimously conceived of at the present stage of its piecemeal decomposition. Everybody is aware of, but few are willing to accept the salient reality where the genuine dichotomy behind the ecumenical pandemonium is neither the controversy between the political systems or camps nor cultural distinctions or even civilizational diversities among big and small ethnic agglomerations. The protagonists of the ongoing drama in reality are Christendom and paganism as two irreconcilable antagonists throughout the universal memory or teleological behest. (Babasyan, December, 2016, pp 115-117).

It is for good reason, therefore, that Hans Morgenthau once coined the true condition of political science:"Political science is of necessity based upon, and permeated by, a total world view-religious, poetic as well as philosophic in nature-the validity of which it must take for granted". (Morgenthau H., 1955, ,p.410). Still spiritually a more pervasive and poetically more inspired reflection of this immature and rather flaccid state is delivered by St. Augustine: "Because I am not full of Thee I am a burden to myself. Lamentable joys strive with joyous sorrows: and on which side is the victory, I know not." (St. Augustine, p 108).

In fact, unless the global developments are construed around the divine predestination the existence of humankind will never make sense.

\section{Main considerations}

In an effort to structure the scenario of the universal catharsis one inadvertently arrives at the same point of departure: the global community does not seem to need cleaning. Thus a two-fold perspective is unfolded: 1) humanity organized into the framework of the global statehood, i.e. the UN sovereignty, is cracking in broad daylight; 2) the Chino-Muslim coalition striving to assume the role of the global mastermind does not seem to be up to this task: what is accepted in the political framework of human activities cannot be seen from the ecclesiastical dimension of divine Providence. The said coalition lacks this mission because this mission is not tailored to it: one has to put up with the implacability of the Word. Any effort to placate it is fraught with waste of time and heavy toll because entreaty in this context is 
equal to a challenge to God insidiously disguised in sham piety and simulated misunderstanding. As H. Morgenthau pointfully notes:"The science of international law and the social sciences in general are still awaiting their Newton, their Leibnitz, their Faraday. . . . In all likelihood, they are waiting in vain." ( Morgenthau, 1940, p. 307).

It is not about scholars working epistemological miracles, it is about modalities toward solving existential problems, to wit something more earnest than one could imagine in one`s academic reveries. One more facet on the problem at consideration is that mainstream science along with the secular administration amply nurtured by the latter proved unable to demonstrate the right decision-making on the global dimension. If we turn to the full- fledged statement of the problem set forth by Brzezinski, we'll find out that in terms of real life even the adamant recipes do not hold water. "Europe,- states Brzezinski, - is America`s natural ally. It shares the same values; partakes, in the main, of the same religious heritage; practices the same democratic politics; and is the original homeland of a large majority of Americans. By pioneering in the integration of nation- states into a shared supranational economic and eventually political union, Europe is also pointing the way toward larger forms of postnational organization, beyond the narrow visions and the destructive passions of the age of nationalism." (Brzezinski, 1997, p. 57). Beyond any doubt this passage contains useful clues toward identifying the genuine problem and discerning its viable solution, though it is set forth in the historical context, and therefore needs to be transmuted into the sacerdotal plane. Let the starting point of this discourse be the "same religious heritage" which logically encapsulates the subsequent items in his enumeration. Now the focal point is 'how do the USA and Europe partake of the common religious heritage'? To the credit of the US be it said that it demonstrates a life-size grasp of the biblical message in its secular applications. Luckily, in this respect America is not alone: a few years ago this experience was backed by Russia in the Northern Caucasus, of late also in Crimea. What does unite the sanguine experiences of these two powerhouses? Their common mission: fighting back paganism in its old and new demonstrations and, along the way, reinforcing the positions of the nation state which we construe as a purely Christian phenomenon (Babasyan, December, 2016, pp 115-117). Typically, Germany of these days is scourged by the unprecedented immigration wave which is going to be a touchstone for the entire continent in that Europe will have to be awakened to its uniquely significant mission: cradle of Christendom. If Europe fails to muster up its resources around Germany and preclude this disaster from continuing, then the whole Christian community throughout Europe and possibly elsewhere will have to slough off its religious consumer slumber and realize that this is the beginning of a pagan onslaught disguised 
in immigration. It sounds more like wishful thinking when Brzezinski talks about 'larger forms of postnational organization'. Sadly enough, the modern political analysts of the West seem to be downplaying the multifarious potentialities of the pagan strategy the most orthodox of which are the spiritual dormancy of the West, its insider traitors, and its fatally wrong stake on allies from among potentially pagan environment simulating allegiance to Christianity (particularly, in Transcaucasia). In fact, hitherto the West has been showing itself wise after the event which cost it tens of thousands of losses in civilian population under peaceful conditions which more and more are resembling the state of undeclared war to which the Western statist system is thoroughly unprepared simply because until recently it was used to waging wars with the visible adversary totally discarding the plausibility of an invisible enemy who does not take long to become visible and audible as he starts knocking at your door, and after you have opened the door threateningly shakes finger at you. So as the things stand internationally there is not a slightest opportunity for the West to enjoy 'postnational organizations'. This is because the West lacks the knowledge of the recurrent cycles in the existence of pagan formations and their bearing in the shaping of global politics. In this respect a conceptual approach is developed by this author in a number of his articles (see, in particular, Babasyan, November 2015, pp. 55-60). The point is that if under current conditions a Western superpower is unable to protect the lives of its civilians in its own territory, any transformation into postnational formation will be accompanied by a weighty presence of paganism in it which amounts to a suicide in matters of politics and, most importantly, of faith.

Much more promising and instrumental in applied terms sounds the following passage: “A larger European framework that involves in varying ways Turkey and Russia would mean that Europe, still allied with America, could become in effect a globally critical player. The resulting bigger West sharing a common space and common principles - would be better positioned to offset the tendencies in some parts of Eurasia toward religious intolerance, political fanaticism, or rising nationalistic hostility by offering a more attractive political and economic alternative."(Brzezinski, 2012, p.153). To my intellectual gratification, Brzezinski`s insight has discerned, behind the grotesque pile-up of internationality, the only infallible way toward hissing the flag of Christendom above the earth.

While looking forward to "new heavens and new earth, the home of justice" (2 Peter 3:13) (The New English Bible,1970) to come it would not be amiss for the alliance of Christian nations to secure, by concerted efforts, the universal victory of Christ Jesus on the globe. After all, can anybody tell where else the mission of global politics lies? The makers of the modern world are surely aware of the fact that their deeds are in the strict lockstep 
with divine guidelines ( e.g. Isaiah 17, 24, 47; Jeremiah 46-51; Ezekiel 2533, and elsewhere throughout the Bible) (The New English Bible,1970). Sometimes, however, God needs a short respite; and it is precisely in this span that the religious acumen of Christian leaders is called for: they are quirky enough to step ahead of God to get His blessings. Of course, God does not stint his blessings also on the sluggishness, but in that case Christian nations should make shift with what they have instead of achieving what they are bound to for God in return for His blessing, because while they are blessed in their indolence, the victory goes to their pagan adversary which is a blatant challenge to God and simultaneously the betrayal of His interests.

Throughout his latest works Brzezinski points out the seminal axis of Europe-Turkey-Russia-USA. At face value it might seem that all choke points are removed out of the way of such an effulgent constellation. In reality, however, things seem to look fairly dim, and the roadmap to follow needs a more feasible scale not only in technical terms but primarily in things concerning the worldview of the demographic context each of the protagonists of the above axis is in charge of. In an effort to dull the edges of the spontaneously developing global events Brzezinski as a true Christian and conscientious researcher is eager to see the modeling of the global paradigm in a logically accurate, teleologically conclusive, and aesthetically inveigling way. "Historic outreach, -he notes, - means that the process of the West and of Russia growing together has to be pursued both patiently and persistently if it is to become truly enduring. The cardinal principle of a strategically minded and historically prudent policy has to be that only a Europe linked to America can confidently reach eastward to embrace Russia in a historically binding relationship." (Brzezinski, 2012, p.149). Brzezinski`s choice of the foregoing pivot toward the future ecumenical stability is not accidental: these four powerhouses are each, in varying degrees, in control of the territorial, ethnic, economic, political, and religious transmutations inside social convergences they formally represent. Yet each of them severally and all of them cumulatively are haunted by the same plague: lack of motivated ideological platform, i.e. implementation tools of the religious doctrine without which proper administration and good governance are implausible. This focal issue, like undercurrent, flows beneath the surface discourses of many international analysts who, for one or the other reason, do not convey the true import of their geopolitical deliberations. This scholarly prevarication is inherent also in Davutoglu`s style who captured the thrust of the discussion yet failed to deliver the true name of the game in his seminal observation: "The first and the most important prerequisite of the first condition is the recognition of the right to survival of several different civilizational identities in an atmosphere of coexistence. The existing civilizational crisis could only be overcome by a 
civilizational dialogue and a free exchange of values. Unicultural monopolization has been the main dilemma of modern western civilization and has led to the destruction of traditional civilizations. The current revival of traditional civilizations is a reaction against this uni-cultural monopolization. (Davutoglu, Dec 1997-Feb 1998, p.7). The overall drawback to this statement is that "revival" is not the appropriate word to employ in a global context where the chips are down and the world community is rumbling down the rough road of historical concatenations towards its eschatological climax. To 'revive' something in this format would amount to turning back time, whereas the general vector of the mundane drift, in compliance with the rules of the global game, is agreed upon the clockwise direction. What can be seen behind sincere wishes and expectations of Davutoglu is the paraphrase that permanent peace should be reached based on the civilizational dialogue and a free exchange of values. However, there are two choke points in this passage which potentially preclude these positive processes from occurring: 1. After the Westernization of the Eastern civilizations there can be no more talking of traditional civilizations due to the latter`s pivotal transformations; 2 . The 'civilizational dialogue' implies more than two participants and therefore the term «polylogue» would be more appropriate in this connection. But even if we replace the 'polylogue' with the 'dialogue' it still will remain unclear who are the protagonists of that dialogue and what and how many back-up participants would represent each of those protagonists on both sides; 3.Suppose the protagonists of the dialogue are the West/Christianity and the East/Islam who can irreproachably deliver the criteria for the partisans of each of the leading parties? For instance, can anybody claim that Armenia of these days is as Christian as Europe or, if anything, less Islamic than Turkey, if one takes account of virtually predominant, though implicitly followed Muslim traditions rife in Armenian society and polity? 4. Furthermore, if we set our minds on structuring the crocks of the so called 'traditional civilizations' into a system of coherent international relationships (the existing geopolitical blocks), we shall ineluctably remold a Colossus of Rhodes whose crocks we have by now (UN, NATO, and the like). The above considerations, on balance, make it clear that the like endeavor would be akin to Sisyphean toil from the very outset. Simply put, if Turkey found its place in Brzezinski s geopolitical axis is less, if at all, due to its being traditional civilization, but rather to the reified efforts by the latter toward introduction and strengthening of the standards of civilized ideology into the political reality of the country and the region. Thus, as it can be seen, a civilized political life and dynamism does not provide for a variety of civilizations accepted on other levels of intercivilizational synergism, and in this way is not polytheistic, but rather precludes any idolatrous 
manifestations inside the context of the monotheistically forged international politics. After all, it makes sense to go to the very root of commonalities of the said quadruple axis. A citation from S. P. Huntington will help do this without any bias: "Peoples and nations are attempting to answer the most basic question humans can face: Who are we? And they are answering that question in the traditional way human beings have answered it, by reference to the things that mean most to them. People define themselves in terms of ancestry, religion, language, history, values, customs, and institutions. They identify with cultural groups: tribes, ethnic groups, religious communities, nations, and, at the broadest level, civilizations. People use politics not just to advance their interests but also to define their identity. We know who we are only when we know who we are not and often only when we know whom we are against." (Huntington , 2003, p.21). We shall take leave to point out the affinity that draws together Turkey with the three other parties of the aforesaid geopolitical quartet, namely: 'We know who we are only when we know who we are not'. This will allow us to leave it over to Turkey to decide upon the final segment of the above statement as to whom it is against. Importantly, after the self-identity is in place, the enemy does not seem to count any longer because in the strict lockstep of nature the selfidentification proceeds based upon equal strength with the peers involved. This implies that Turkey, basically having coped with its pagan past, and entrusted by its Western colleagues with joint molding of the correct world to come, can logically and imminently have one adversary whose name it knows full well.

The phenomenal thing about the seeming controversy "secularism vs. sacerdotalism", and at the first glance paradoxical, too, is that the genuine sacerdotal value of the social order can be revealed only against the backdrop of the secular polity. We would like to see the perspective for this interplay to eventually morph into a theocracy at some time in the future, yet the rub is that at this point the borderline of this future is hardly discernable against the sky-scape of the numinous ecumenical developments. In broad terms, this can be explained by the following lines from Brzezinski: "States, like individuals, are driven by inherited propensities - their traditional geopolitical inclinations and their history - and they differ in their ability to discriminate between patient ambition and imprudent self-delusion." (Brzezinski, 2012,, p.78). The balance between a patient ambition and imprudent self-delusion is a wishful category only because they both alike are the life-size manifestations of the desirable projections. And altogether mankind in its organized forms (nation states) can serve the will of God and in this way only stay alive or survive because when unorganized (pagan public formations whipped into shape after the Western stencil, or worded differently, "failed states") normally does not exist or comes very close to 
the brink of extinction where it dawns on it that in all its motivations it is divinely driven. It transpires, sad as it sounds, that all its life span between the self-courted cataclysms mankind exists subliminally with the only naturally preordained chance of lucidity when at the peak of its only feasible option of creativity, i.e. self-destruction. As it can be seen, when out of step with divine instructions, mankind is exposed to a durable existential death dubbed «life» which in reality is nothing less than a lethal malady. Logically, the only rationale of this conundrum is that humans experience a real life only at the point of illumination which is the result of a boring path they pound toward the first-hand contact with God. Hence the meaning of the lifelike death for man is to reach the exciting mortal acme where the eternal life commences which in other words is called acceptance of God or repentance. This ondition, however, can be obtained also throughout corporal span of man`s existence, but only through faith in Christ Jesus. That s how the domination of Christianity as the globally reigning religion can be explained: everybody is looking for the salvation from burdensome weight of fictitious life; and that's for good reason for the realm of sin, i.e. spiritual illusion through the prism of corporal life, in reality has but a very limited temporal duration, and humanity gets bothered with having to go through the same condition of death over again. It needs to be severed from the claws of death for good. Here is where the divine promise proclaimed by Christ Jesus comes to remove sorrows out of the way of humankind: "Come to me all, whose work is hard, whose load is heavy; and I will give you relief. Bend your necks to my yoke, and learn from me, for I am gentle and humblehearted; and your souls will find relief. For my yoke is god to bear, my load is light." (Matthew 11:28-30) (The New English Bible, 1970).

One has to take for granted that if not in lockstep with the above admonition, people are doomed to a recurrent life cycle which slightly, if at all, differs from that of insects and other species of the animal world. Under these grave psycho-spiritual conditions the political science, if anything, is still able to provide a faint comfort in that it tries to work out a rationale for the globally reigning foul-up: "More broadly, -states Huntington, -the religious resurgence throughout the world is a reaction against secularism, moral relativism, and self-indulgence, and a reaffirmation of the values of order, discipline, work, mutual help, and human solidarity." (Huntington, 2003, p. 98). Ironically, politics is the consolidation of human wills around a valuable religious concept less the will of God. Hence the only achievement of this process is the resulting convergence of secularism and clergy into a value system that is man-made and man-run, and so is never fated to be representative of God, which implies that it is prone to crack at certain intervals. Each time this happens, i.e. mankind is thrust back to the original sin, the old wheel is spun again, and this is what they call history. If 
anything , the original sin seems to be the only milestone in the human history because savoring apples from the tree of knowledge and playing good and evil against each other, indeed, did not help people to obtain any valuable knowledge, except for an expert lie which logically is downright explicable because through the lie people still hope to get to the very tree of life, which, incidentally, is but a waste of time for through sacrificing his only Son on Golgotha God has taken care of eternal life as well. Anyway, rushing about between Eden and Golgotha, mankind is largely left to its own devices to make its final choice. What will be the fallout from it, is the plot of the final chapter of the human history, though essentially everybody can see behind the squalor of its upshot: "And the present heavens and earth, again by God 's word, have been kept in store for burning; they are being reserved until the day of judgement when the godless will be destroyed." (1 Peter3:67) (The New English Bible, 1970).

Thus the godless, to wit pagans, constituting the very lynchpin of global bellicosity, and in this way the antipode of peaceful community (West-prone civilizations), shall be considered a specific type of humanity with inherent and blatant deviations in terms of social and inter-cultural coexistence. Their illness was diagnosed back at the dawn of civilization and runs as follows: "He shall be a man like a wild ass, his hand against every man and every man`s hand against him; and he shall live at odds with all his kinsmen.” (Genesis 16:12) (The New English Bible, 1970).

\section{Conclusion}

"Peace" , as conceived of by the mundane political doctrine and supported by international practice, is a brittle, makeshift, deceptive, and destructive category in that eventually it is aimed at unleashing war in its most devastating and unruly forms. In that respect 'war' and 'peace' are the two sides of the same coin. Most flagrantly, everyone of those playing this pathetic 'heads-or-tails' -game under contemporary conditions has one thing in view: to carry out as cruel demographic cleansing as possible.

The driving motif behind contemporary wars, as distinct from those in the previous epochs, is neither the royal ambition to immortalize one`s fame nor the imperial penchant for alluring geographical discoveries with the prospects of fabulous enrichment. Numerical purging is rather the end purpose of any present-day war, and this is not occasional: the «immense treasures» piled up until now prove insufficient for ever increasing global population. This situation is largely due to the disproportionate growth of the "quantity vs, quality" ratio where the numerical growth of consumer demands of the global community drastically prevails over the qualitative prerequisites for the harmoniously interdependent development. 
The above condition can full well stand for the globalization, to mean globalized human problems. Even a fleeting survey, in this regard, will discover that at the back of the said phenomenon is the cultural deficit with the majority of the world`s population. This in turn is to be imputed to their cultural status characterized by an obvious discrepancy between the numinous precepts of their traditional religions and the growing tangible demands of their physical lives.

The foregoing fissiparous image of the global developments should otherwise be called the "Grand Divide" between Christianity as the religion that brings salvation and solution to all chokepoints and the paganism which keeps heavily creating them. The inconsistency of paganism inevitably leads to aggression as the aggregate expression of the huge universal gap of individuality which on the political level is fraught with the foul-up we are facing now.

One has to be mindful of the political destructiveness with which the paganism has colored the overall global image (globalization). Only the realization of this fatality will clear the road to the hearts and minds of humanity in terms of accepting Christianity not only as the religion in the traditional, mainstream, or, say, institutional sense of the word but also as a superhuman condition toward general enhancement of the quality of institutionalization. As R.A. Saunders points it out: «As an outgrowth of the Romantic Era, neopaganism evolved in lockstep with the spread of nationalism, and yet neopaganism has paradoxically been strengthened by the weakening of the nation state in the face of globalization.» (Saunders, 2012, p.797). Very useful observation, indeed, because basically it is due to the consolidated efforts of pagan movement that the weakening of the nation or as we put it Christian state could have taken place. By the same token, this weakening of the Christian culture, as we repeatedly pointed out in a number of articles (Babasyan, June 2015, pp.29-53), is also largely due to the spate of religious consumerism that has swept over Western civilization over some time past. The component of faith as the driving force behind the magnificent socio-cultural architecture has been significantly neglected the result of which is the worldwide devastation that has brought us together under the roof of problems of our own making where mutual reprimands won`t yield effect any longer. So in order to avoid further exacerbation one needs to put in place the only viable and tested tool of social building and spiritual revival: the Christian doctrine. It is everybody`s concern that integrity - a divine category - should be established globally at long last.

By the same token, the only modus operandi of both 'integrity' and 'justice' as the two causa sine qua non of permanent peace in the civil circulation, understandably, is the nation state, Remarkably, underestimation of the Christian doctrine in moulding up the administrative pattern of the 
nation state has led to the situation where the Western political culture is oblivious of the obvious fact that the permanent peace was established nearly 2000 years ago: "But now in union with Christ Jesus you who once were far off have been brought near through the shedding of Christ's blood. For he is homself our peace. Gentiles and Jews, he has made the two one, and in his own body of flesh and blood has broken down the enmity which stood like a dividing wall between them; for he annulled the law with its rules and regulations, so as to create out of the two a single new humanity in himself, thereby making peace. This was his purpose, to reconcile the two in a single body to God through the cross, on which he killed the enmity". (Ephesians 2:13-16) (The New English Bible, 1970). Logically, the only thing the modern Western administrators are entrusted with is to maintain this modus vivendi (Church of Christ) pulled off by our Lord.

Finally, in technical terms, the modality of permanent peace is sustained by aligned implementation of 3 divine qualities man has inherited from his Creator:

Choice (repentance, i.e. self-identification in Christ). "For through the law I died to law - to live for God. I have been crucified with Christ: the life I now live is not my life, but the life which Christ lives in me; and my present bodily life is lived by faith in the Son of God, who loved me and gave himself up for me”. (Galatians 2:19) (The New English Bible, 1970);

Assessment or the ability to perceive the civil society as the Living Church of Christ or Christ's Body: "He is the head, and on him the whole body depends. Bonded and knit together by every constituent joint, the whole grows through the due activity of each part, and builds itself up in love". (Ephesians 4:16) (The New English Bible, 1970). One more instrumental comparison to the "temple of God" is provided in 1 Corinthians 3:16-17;

Creativity or conscious willingness to serve that very society for the sake of the Saviour because: "As the body is dead when there is no breath in it , so faith divorced from deeds is as lifeless as a corpse." (James 2:26) (see also 1 John 3:18-19) (The New English Bible, 1970). Under civil conditions of secular reality this preparedness is primarily expected from Western politicians and government authorities in charge of the above work. The Bible vests them with full authority on the grounds that they are:

"A chosen race, a royal priesthood, a dedicated nation, and a people claimed by God for his own, to proclaim the triumphs of him who has called you out of darkness into his marvellous light." (1 Peter 2: 9-10) (The New English Bible, 1970). 


\section{References:}

1. Babasyan T. M, “Covert Actuality. Stray Cultures Launch World War III.”, International Journal of Education and Social Science, vol 2, November 2015

2. Babasyan T. M,“"Secular Economy as Viewed from Christian Perspective”, The 21-st Century, June 2015.

3. Babasyan T. M., Symptomatology of the Gentile Species, 21-st Century, December, 2016

4. Brzezinski Z. K., Grand Chessboard, 1997.

5. Brzezinski Z. K.,, Strategic Vision. America and the Crisis of Global Power, 2012

6. Davutoglu A., 'The Clash of Interests: An Explanation of the World (Dis)Order', Perceptions Journal of International Affairs, Vol. 2, No. 4 (Dec 1997-Feb 1998

7. De Soto Hernando, the Mystery of Capital,2000,

8. Huntington S. P., The Clashes of Civilizations and the Remaking of World Order, 2003

9. Keynes J.M., The General Theory of Employment, Interest, and Money,

10. Max Weber, Politics as a Vocation, 1919;

11. Max Weber, Wirtschaft und Gesellschaft, 1921;

12. Morgenthau H., "The Commitments of Political Science"(1955), in The Decline of Democratic Politics,p.410.

13. Morgenthau H., ("International Law"(1940), in The Decline of Democratic Politics, p. 307

14. P. Vicente and D. Kaufmann, Legal Corruption, 2006;

15. Sabine G.H, A History of Political Theory, 1958

16. Saunders R. A., Towards a religiogeography of neopaganism, Progress in Human Geography 37(6) 786-810, 2012, p.797

17. Seagle W., the History of Law, N.Y.1946, p.23

18. Spencer Herbert, The Man versus the State, The Caxton Printers, LTD. Caldwell, Idaho, 1960; Ehrlich Eugen, Fundamental Principles of the Sociology of Law,1936;

19. St. Augustine, Confessions, p 108

20. The New English Bible, Oxford University Press, 1970. 